\title{
INTERNATIONAL RELATIONS AS A SYSTEM AND A DISCIPLINE: FROM THE WESTPHALIAN TO THE POST-WESTPHALIAN WORLD ORDER
}

\author{
Stosunki międzynarodowe jako system i dyscyplina: \\ Od westfalskiego do postwestfalskiego porządku światowego
}

\begin{abstract}
The review is devoted to the analysis of scientific work of Amitav Acharya and Barry Buzan, The Making of Global International Relations. Origins and Evolution of IR at its Centenary (Cambridge and New York, Cambridge University Press, 2019, 383 p.). Structurally, the work consists of an introduction and ten sections. Well-known Western theorists of international relations gave their vision of the evolution of the Westphalian world order during the twentieth century. They also revealed the reasons and nature of the transition of the world order to Post-Westphalian international relations after 1989 and substantiated the causes, principles and effects of the emergence and development of knowledge about International Relations. Based on the study and critical rethinking of the theory and practice of international relations of the XX - early XXI century (until 2017/2018) the authors singled out several meaningful blocks. This grouping allowed us to state the modernization of the Westphalian model of international relations and the formation and development of the science of International Relations in the Center and in the Periphery under the influence of a number of fateful events. First of all, we are talking about the impact of the two world wars, bipolar confrontation and the process of decolonization on the evolution of the Westphalian international system. The genesis of the discipline of International Relations after the end of the First World War was accompanied
\end{abstract}

1 Dr. habil. Alla Kyrydon, Professor, Director of the State Scientific Institution "Encyclopedic Publishing House" (Kyiv, Ukraine); e-mail: akyrydon@ukr.net, ORCID: 0000-0003-4375-5350

2 Dr. habil. Sergiy Troyan, Professor of the University of Rzeszow, Professor of the Department of International Relations, Information and Regional Studies of the National Aviation University (Kyiv, Ukraine), e-mail: kattis@ukr.net, ORCID: 0000-0002-3053-6530 
by the active expansion of its institutionalization, subject field and the inclusion of the periphery in this space. Radical changes in the world and international relations after 1989 led to the globalization of international relations and the final formation of the Post-Westphalian world order. The conceptual analysis of the evolution of international relations during the XX-XXI centuries on the basis of fundamental research by Western scientists and also theorists from outside the Western core allows us to state their essential changes under the influence of two world wars, globalization, decolonization and changes in the ratio of forces between the Center and the Periphery.

Keywords: international relations, Westphalian international system, world wars, Cold War, decolonization, post-Westphalian world order

Streszczenie: Recenzja jest poświęcona analizie pracy Amitava Achary'ego i Barry'ego Buzana, The Making of Global International Relations. Origins and Evolution of IR at its Centenary (Cambridge and New York, Cambridge University Press, 2019, ss. 383). Strukturalnie praca składa się ze wstępu i dziesięciu części. Znani zachodni teoretycy stosunków międzynarodowych przedstawili swoja wizję ewolucji westfalskiego porządku światowego w XX w., ujawnili powody i charakter jego przejścia po 1989 r. do postwestfalskich stosunków międzynarodowych oraz uzasadnili przyczyny, zasady oraz skutki powstania i rozwoju wiedzy o stosunkach międzynarodowych. Na podstawie badań i przemyślenia krytycznego teorii i praktyki stosunków międzynarodowych XX - początku XXI wieku (do 2017/2018) wyróżnili oni kilka znaczacych bloków. Takie zgrupowanie pozwala skonstatować modernizacje modelu westfalskich stosunków międzynarodowych oraz tworzenie i rozwój nauki o stosunkach międzynarodowych w centrum i na peryferii pod wptywem szeregu znaczacych wydarzeń. Przede wszystkim mowa o wptywie dwóch wojen światowych, konfrontacji dwubiegunowej oraz procesu dekolonizacji na ewolucje westfalskiego systemu międzynarodowego. Genezie dyscypliny stosunków międzynarodowych po zakońzeniu I wojny światowej towarzyszyto aktywne rozszerzenie jej instytucjonalizacji, pola tematycznego, a także wtaczenie peryferii w te przestrzeń. Radykalne zmiany świata i stosunków międzynarodowych po 1989 r. doprowadzity do globalizacji stosunków międzynarodowych i ostatecznego uksztattowania postwestfalskiego porzadku światowego. Analiza koncepcyjna ewolucji stosunków międzynarodowych $w$ XX-XXI w. na podstawie fundamentalnych badań zachodnich naukowców i również teoretyków spoza jądra zachodniego pozwala nam określić ich zasadnicze zmiany pod wptywem dwóch wojen światowych, globalizacji, dekolonizacji $i$ zmian w stosunku sit między centrum i peryferiami.

Słowa kluczowe: stosunki międzynarodowe, westfalski system międzynarodowy, wojny światowe, zimna wojna, dekolonizacja, postwestfalski porzadek światowy 


\section{Introduction}

Transformations and systemic changes at the European and world levels at the turn of the 1980s and 1990s had a profound effect on international relations. The collapse of the Soviet Union and the world communist system meant the end of the Cold War and the bipolar world. The policy of openness of Russia and China and their inclusion into global economic, political, social processes together with the formation of an integration core in Europe (European Union), Eurasian space (Eurasian Economic Community - until 2014, Eurasian Economic Union - since 2015), America (North American The Free Trade Agreement, Latin American Integration Association), Asia (Association of Southeast Asian Nations and ASEAN Free Trade Agreement, Asia-Pacific Economic Cooperation), Africa (African Union, New Partnership for Africa Development) marked the final transition to the globalization of international relations. The information revolution and the advent of the Internet age have led to the virtualization of space and even more blurred interstate borders. Finally, globalization, integration, trans-nationalization, and virtualization of international relations have strengthened the influence of non-state actors on world politics. States, as international players in the new post-bipolar realities, use as important means of influence, not just force and diplomacy, but also tools of soft or even smart power, hybrid warfare, digital diplomacy.

These arguments allow us to draw a conclusion about the transition of modern international relations not just to a new system, but also to a new world order quality. This means the final end of the Yalta-Potsdam bipolar era of the Cold war and that it was replaced by the first unipolar post-bipolar system, which as a result of the "rise of others" has already been evolving towards a multipolar one since the beginning of the XXI century. But world order changes are much deeper and mean more than just the modernization of the state-centric Westphalia world order, which developed in the middle of the XVII century. In fact, deep systemic and structural changes of the late XX century in the international arena had as their main consequence the destruction of the Westphalian world order. The entire modern world order has been radically changed by globalization of international relations, blurring of traditional state borders, creation of a powerful over/inter-state integration spaces, the increasing role of the non-traditional (non-state) international actors, virtualization, diplomacy and even space military operations and transition of inter-state 
and international military confrontations into cyberspace, and paramilitarization and paradiplomacy of international relations. Taking these changes into account, it can be stated that they are the evidence of the fast and real emergence of the global post-Westphalianworld order in modern conditions.

Scientific studies and understanding the relevant paradigmatic realities of the causes and consequences of the end of the Westphalian international era can be seen as a certain ideological challenge for researchers of history and theory of international relations. In this context, we would like to draw attention to the fundamental work of the Distinguished Professor at the School of International Service, American University, Washington Amitav Acharya and Emeritus Professor in the London School of Economics Department of International Relations, Honorary Professor at Copenhagen, Jilin and China Foreign Affairs Universities, and a Fellow of the British Academy Barry Buzan The Making of Global International Relations. Origins and Evolution of IR at its Centenary (Acharya, Buzan 2019). Well-known Western scholars have set themselves several goals, in particular, to deepen the understanding of international relations of the XIX - early XX centuries and show the relationship with their subsequent evolution; focus not only on classical but also on non-Western approaches to international relations within the study period; finally, to submit an introductory text on the history of the evolution of international relations as a scientific discipline (Acharya, Buzan 2019: 2).

Structurally, the work consists of an introduction and ten sections. For convenience, they can be characterized by several content blocks.

\section{The World and foundations of International Relations up to $\mathbf{1 9 1 9}$}

Describing international relations in the early twentieth century, the authors focused on several notable central themes. In particular, it is about the influence of the revolutions of the XIX - early XX centuries and the colonial policy of Western states on international relations, the rise of Japan as the first step to "the rise of the rest" (Zakaria 2009), as well as the trauma of the Great War of 1914-1918 and its impact on the evolution of the Westphalian international system and the beginning of disciplinary science of international relationships. Amitav Acharya and Barry 
Buzan proved that the century before the First World War was deeply revolutionary and transformational and led to structural changes and peculiarities in the evolution of international relations (Acharya, Buzan 2019: 29-30). However, although the international system was weakened by the first global armed conflict, it has not fundamentally changed in most respects.

For world politics, since the Great War, there were two big shocks from this war. One was the unleashing of the contradictions inherent to the ideologies of progress into the international political arena. The First World War set loose a three way ideological rivalry between Socialism, Fascism and liberal democracy, with monarchies pushed to the background. The other big shock was the legitimacy and viability of the great war of power as an instrument of policy (Acharya, Buzan 2019: 31-32). The authors argue that the aftermath of the First World War contributed to a kind of reset of the old agenda. Since their foundation in 1919, new international relations were "obsessively focused" on the trauma of the First World War and sought to prevent a recurrence of such disasters. At the same time, all this fundamentally affected the founding of International Relations as a recognised academic discipline. the contemporary field, or discipline (opinion varies), of international relations, conventionally dates its origin to 1919, when its first university chairs and think tanks were set up, and "International Relations" became one of several labels (International Studies, International Politics, World Politics) for a specific field of study. As it was needed to manage the international anarchy of great power relations, arms racing and the world economy became the overriding priority of the "new" discipline, in order to prevent another war.

As Amitav Acharya and Barry Buzan proved, during the nineteenth century and up to the First World War, the nature and practices of International Relations were structured by a profoundly unequal relationship between a relatively small, but very powerful core (Western plus Japan), and a large, but relatively weak periphery (Acharya, Buzan 2019: 34-66). The practice of core was to make a sharp distinction between "civilized" states, who composed international society, and "barbaric" or "savage" societies, mostly dealt with by degrees of colonial subordination and not counted as part of the international community.

The development of International Relations during this period was much more significant than suggested in the founding myth of 1919. This means that majority of the foundations of modern IR was developed 
before 1914. This "IR before IR" mirrored International Relations in its concerns and definitions, being almost entirely a view from the core. Despite the trauma of the First World War among the core, the highly unequal colonial relationship of core-periphery carried over largely unaltered into the interwar period. Throughout this time of extreme core dominance, views about International Relations were developing in the periphery. But since many of them were motivated by anti-colonialism, they were largely ignored or marginalized in the West-centric discourses of International Relations. The colonies were mostly excluded from international society in their own right, and they were hardly a part of International Relations concerns during this period either.

We draw particular attention to the argument of Amitava Acharya and Barry Buzan that the main foundations of International Relations were laid down during the several decades before 1919. The International Relations of the nineteenth century was very much a view of the world, reflecting the concerns of the core powers. Meanwhile, it is possible to trace only a few early instances of modern International Relations thinking outside the West (Acharya, Buzan 2019: 34, 55-64). However, despite the existence of International Relations before the early XX century, it was not until the First World War that the foundations of the science of International Relations had finally been completed. The priority of the discipline was the problems aimed at preventing war and maintaining peace.

\section{International relations in 1919-1945 and the establishment of the discipline}

Amitav Acharya and Barry Buzan rightly noted that the First World War can perhaps be perceived best as the first round of a systemic crisis of modernity on a global scale. Subsequent rounds of this crisis - the Second World War, the Cold War and decolonization, the "rise of the rest" - occupied much of the twentieth century (Acharya, Buzan 2019: 67). Interwar international politics and World War II became much more significant global crises for the Westphalian order than the Great War. World Wars I and II, the Cold War and decolonization were not exactly distinct events, but phases of a more general crisis. They dramatically influenced the modernization of international relations in the twentieth century. 
In the interwar period, in the attempt to rebuild and improve postwar order during the 1920s and in the progressive collapse of that order during the 1930-s., anti-colonialism became more organized in Vietnam, India, Indonesia and many parts of the Middle East. The colonial powers had to deal not only with intellectual and political opposition fuelled in part by Wilsonian rhetoric of the right of self-determination but sometimes with fierce protests and insurgencies. However, during the interwar years, colonial concerns were much more along the geopolitical lines of competition between the great powers to re-divide the colonial spoils, with Britain, France and the United States as the status quo powers, and Germany, Italy, Japan and, up to a point, the Soviet Union as the revisionist ones. The colonial powers still enjoyed a significant advantage over the periphery in the fields of authority and development (Acharya, Buzan 2019: 73-74).

All this only added tension to interwar international relations. The three-way ideological division (the liberal democracies - fascism communism) turned balance-of-power, and balance of threat, into calculations, very tricky and complicated. Such calculations were complicated by the rapid changes in the military balance being created by German, Japanese and Soviet rearmament, and the responses to them in France, Britain and the United States. These changes were not only quantitative (how many aircraft, ships, tanks, troops), but also qualitative. In this situation, there was no hope of creating a system of collective security and peace.

World War II became a new stage in the crisis of modernity, which World War I had begun. At the same time, as aptly noted by Amitav Acharya and Barry Buzan, social Darwinism and nationalism remained powerful influences on the conduct and rationalization of international relations, and in the Fascism, it took an even more extreme form than they had prior to 1914 (Acharya, Buzan 2019: 78). The Second World War was much larger in scale and intensity than the First. It was, in effect, the merger of two regional wars: one in Europe, which was round two of the First World War (war against Germany), and the other in Northeast Asia (war against Japan). This merger of two regional wars nevertheless made for a truly global world war with much larger imperial stakes. During the First World War, only the Middle East was seriously contested, whatever wider dreams Germany might have had about getting the British out of India. Elsewhere, as in Africa and East Asia, the mopping up of German colonies was a relatively minor affair. But during the Second World War, not only were the Middle 
East and North Africa at stake, but also the colonial empires in South and Southeast Asia. For a time, Germany and Italy threatened Britain's position in the Mediterranean and Egypt, and Japan took control of Southeast Asia and threatened India. New and improved weapons extended the range of military operations, and, except for the United States, brought the home front much more intensely into the conflict, most notably by the heavy bombing of cities. Some idea of the difference that both the wider scale and the new technologies made to great power war can be seen from the comparable casualty figures: roughly 15 million for the First World War and 41 million for the Second (Acharya, Buzan 2019: 79).

Because of these differences, the consequences of the Second World War were also much larger than those of the First. The main one was the elevation of the United States (the ending of US isolationism and the transition to global engagement) and the Soviet Union to superpower status (these states received large spheres of geopolitical influence, had powerful material potentials, possessed nuclear weapons and the most advanced military technologies) and the shift from an ideologically and materially multi-polar structure to one that was bipolar both in the distribution of power and in its narrowing of the ideological rivalry driving world politics to that between two versions of universalism: liberal-democratic capitalism and totalitarian communism. It caused the delegitimation of colonialism/imperialism as a primary institution of global international society, and its replacement by development. A corollary of this was the rapid abandonment of formally divided sovereignty, its replacement by universal sovereign equality, and the beginning of a great expansion in the membership of the global international society. As a result of World War II, these are the main features that dominated international relations until the late 1980-s.

At the same time (in 1919-1945) disciplinary institutionalization of International Relations took place. That process was strongly influenced by changes and transformations in the international arena that were taking place at the core of the international system and on its periphery. Despite this institutionalization, there was still no agreement on the name of the field. Although some early books did carry the term "international relations" or "international politics" in their titles. It should be noted that the processes of disciplinary institutionalization took place primarily in the core of the international system and had little impact on its periphery (with the exception of Japan and, to some extent, India, China, the Islamic 
world and Latin America). Anti-colonialism was a common theme and motivation for much of the International Relations thinking in the periphery. During the interwar period, International Relations became significantly institutionalized as an academic discipline, mainly in the West, and particularly in the Anglosphere, but also to some extent more globally. Western Idealists and Realists were more concerned with war between the Western nations and the international anarchy problem, and only peripherally with imperialism. But thinkers in the Non-Western world were primarily concerned with imperialism and colonialism.

\section{The world after $\mathbf{1 9 4 5}$ as an era of the Cold War and decolonization, the second foundation of the discipline of International Relations}

The key developments in International Relations were the package of bipolarity, the Cold War and nuclear weapons on the one hand, and decolonization on the other. The first of these played very powerfully from ir into core international relations, but the second did not. Decolonization played strongly into international relations in the periphery. Even though there were many significant changes, they were changes in the system of international relations, not changes in the system itself. International relations were still set up as a system of states, and many of its defining primary institutions remained in place.

At the same time, it is necessary to understand the fact that there are some limitations in the concept of bipolarity and the explanation of the Cold War era, and Barry Buzan drew attention to this in his earlier work (Buzan 2004). Polarity theory distinguishes only between great powers and the rest. It neglects the distinction between great powers and superpowers, which arguably remains of considerable consequence to how global international relations work. Following this thinking, during the Cold War, global international relations had two superpowers and several great powers: China, the European Community, arguably Japan. The same error was repeated after the implosion of the Soviet Union. Unipolarity was widely declared, but in fact, the structure was one superpower and four great powers. There is a massive structural difference between a system with only superpowers and minor or regional powers and one in which great powers are standing between the superpower(s) and the rest. But 
in general, the dominant influence of bipolar division and confrontation during the Cold War was perceived as a determining factor influencing the entire international system. The United States and the Soviet Union were the big winners of the Second World War and functioned as the two dominant centres of military power and ideological competition.

The two superpowers and their allies competed for influence and allies within the Third World, where the key theme of international relations for the periphery was decolonization. The determining factor in international relations was the peaceful and armed struggle for independence. As a result, by 1975, colonialism as a formal political structure of unequal core-periphery relations was over. Western researchers drew attention to the fact that the process was complicated and controversial (Buzan, Wæver 2003). At the regional level, Third World states had to work out economic, political and security relationships with their newly independent neighbours, and develop policies for operating within their regions. This was often far from easy. Many of the new regions were born into conflict. As Barry Buzan and Richard Little argue, the great expansion in the number of states brought about by decolonization created something of a crisis, even for the standard bilateral practices of diplomacy (Acharya, Buzan 2019: 128).

Thus, during the Cold War, under the influence of the processes of bipolarity (confrontation of superpowers and their blocs) and decolonization (change of colonial status to independence), the core and periphery of international relations were transformed. Amitav Acharya and Barry Buzan aptly remarked: "The Cold War and decolonization occurred side by side and played into each other in myriad ways" (Acharya, Buzan 2019: 131). But During this period, the periphery remained largely weak and dependent on the core. Only a handful of Asian Tigers and then, to some extent, China made the jump fully into modernity. During this period, international relations became truly global in the sense that all peoples - or more accurately, all governments - now participated in it independently. But global international society was still dominated by the West, and the Third World was still weakly placed within a core-periphery global economy.

The Cold War ended at the turn of the 1980s and 1990-s. The unification of Germany, the "velvet revolutions" in Eastern Europe, the collapse of the USSR and the world communist system not only ended the era of bipolarity and the Cold War. The whole epoch of the Westphalian world 
order came to an end and was replaced by the post-bipolar/Post-Westphalian world of international relations. Specifically, the United States, and, more generally, the West and Japan, can be said to have won the Cold War. Either way, the Soviet Union and its ideology were clearly the big losers of the Cold War. The ending of the Cold War brought both bipolarity and the nuclear defence dilemma to an abrupt end. The United States seemed to stand alone as the sole superpower.

During 1945-1989 there was active development of the disciplinary base of International Relations. Western researchers note that a key feature of the "second founding" of International Relations after 1945 was both the great expansion of its academic institutionalization in terms of teaching, university departments, think tanks, textbooks and journals, and the founding of mostly national, academic associations of International Relations (or more commonly the broader "International Studies") to replace the International Studies Conference (Acharya, Buzan 2019: 142). These developments were mostly in North America and Western Europe, though for this period, we move Japan and Korea from the periphery to the core. As during the interwar years, no consensus emerges about what to call the discipline, with several labels remaining in play. By the end of the Cold War, International Relations has been spreading the more academic approach from the core to the periphery, becoming more of a formal discipline there. Wherein in many ways, the institutionalization of International Relations in the core followed a similar pattern to that of the interwar years.

The United States is rapidly becoming the most popular and influential country in the discipline of International Relations, due to its transformation into a global force (superpower). In line with its size, wealth and new global roles, the United States mainly led in these developments and was certainly the biggest in most respects. It was American colleges and universities where subjects on International Relations were taught. Separate international relations schools emerged, such as the School of International and Public Affairs at Columbia (founded in 1946), the School of International Service at American University (1957) and a similar school at Denver (a graduate school of International Studies in 1964). Similar institutional expansions took place elsewhere, albeit mainly in the Anglosphere, and places such as Scandinavia where English was strong as a second language. In Western Europe, 19 International Relations think tanks were formed, in the United States another 18, and in Japan 3 (Acharya, 
Buzan 2019: 143). In general, at the stage of the "second founding" occurs a massive expansion of institutionalization in terms of teaching, research and publications, especially in the core, a notable shift from being a broader intellectual and political subject to being a more professionalised, theorised and academic one (Ashworth 2014: 256) and the beginnings of recognition in the core for International Relations thinking from the periphery.

But the discipline remained overwhelmingly dominated by the West (Acharya, Buzan 2019: 178) because of the predominance of core power and core concerns about bipolarity and nuclear weapons, as well as a host of other factors such as limited resources, lack of interest in theory and method, and the large policy and empirical orientation of scholars in the periphery. There were the beginnings of engagement between International Relations in the core and the periphery. By the 1980s Realism, Liberalism, and their variants were already beginning to encounter challenges from Feminism, Post-colonialism and other Critical Theories. International Relations theory was basically geared to constructing the Western experience in universalist terms. Although decolonization was a significant change in ir, seen from the core, it looked vastly less important than the huge zero-sum game of the Cold War's ideological and nuclear rivalries. Yet some International Relations from the periphery was beginning to register in the core, and this trend was to pick up significantly during the 1990-s. The academic study of International Relations in the periphery has not had sufficient coherence or scale to follow the institutionalization pattern in the core yet. Academic International Relations associations were scarce, although a notable exception was the formation of the Mexican International Studies Association.

\section{World and International Relations after 1989: "unipolarity", globalization and the rise of the rest}

Amitav Acharya, Barry Buzan and their followers consider modern international relations in the chronological framework of 1989-1991 through the prism of several perspectives: US hegemony, the powerful influence of globalization on international relations, the rise of the rest and Post-Western world order towards global international relations. 
The main result of the previous Cold War era was the defeat and the collapse of the USSR and the Communist bloc. The United States remained the only superpower in the post-bipolar world. This point of view has found a comprehensive justification in academic and political circles, in the works of supporters of neorealism and neoliberalism, who occupied leading positions among scientific trends in the study of International Relations (S. Huntington, E. Kapstein, M. Mastanduno, W. Wohlforth) (Huntington 1999: 35-49; Kapstein, Mastanduno 1999; Wohlforth 2009: 28-57). Western scholars identify seven key structural features of global international relations: global economy, distribution of power, the nature of great powers, scientific knowledge and technology, common destinies, regulatory structures, and conflict and violence (Acharya, Buzan 2019: 266-278).

Due to the collapse of bipolarity and the success of decolonization, the inclusion of Eastern European states, as well as China and the vast periphery into the global processes, globalization has accelerated significantly. Figuratively speaking, the great shrinkage of the planet has been accelerating into unprecedented levels of global interdependence (Acharya, Buzan 2019: 261). Trans-nationalization and transnational challenges, while strengthening the role of economic relations on a global scale, lead to the blurring of borders of traditional world politics and the undermining of the classical, exceptional value of state sovereignty. Substantial changes are taking place in the relationship between the centre and the periphery. In fact, against the background of strengthening the US hegemonic positions in the 1990s, the rise of the rest took place in the following decades, primarily in China, Russia, Japan, India, Turkey, Brazil, and Mexico. At the same time, the financial and economic crisis of 2008-2009, Brexit, the foreign policy of the Trump administration, the migration challenge for the European Union, the undermining of the foundations of international law by Russia were evidence of a general crisis of liberal democracy and capitalism in general. Hence, globalization, the crisis in the system of liberal democracy and capitalism, the rise of the rest are increasingly causing several important changes in the post-bipolar/ Post-Westphalian world order. First, international relations are becoming increasingly pluralistic, and connections between actors in world politics are becoming networked. Second, the role of non-state international actors is growing, and the internal structure of modern international relations is being modernized. Third, the active involvement of the great periphery into international relations transforms the world into a global society, and 
international relations take on the character of global international relations. Fourth, given the above, in general, the Post-Western world order is evolving in the direction of global international relations. Of course, such changes within the Post-Westphalian world order are far from complete and, according to researchers, will be occurring over the next few decades.

At the same time, the corresponding processes in international relations after 1989 contributed to the active development of the disciplinary subject field and theoretical and applied research in this scientific field. Already the previous stage - 1945-1989 - gave a powerful development of the institutionalization of International Relations, the expansion of the territorial sphere and the subject field of research. The post-Westphalian period is characterized by the further rapid development of the discipline of International Relations. In this case, we note the fact of maintaining the leading positions of the United States and Western Europe, which is the key scientific importance of neo-realists (Z. Brzeziński, F. Fukuyama, S. Huntington, K. Waltz), neoliberals (R. Keohane, J. Nye), postmodernists (J. Baylis, S. Dalby, R. Walker). The point of view that IR needs to break out not just from the "prison of Political Science" but also from the ghetto of its Eurocentric view of history retains its relevance (Acharya, Buzan 2019: 319; Rosenberg 2016: 127-153).

However, in the disciplinary sphere of International Relations of the Post-Westphalian period, further substantial changes are also taking place. On the one hand, they are associated with the active involvement of peripheral countries in the study of International Relations, Western trends continue to dominate the scientific discourse, though. On the other hand, new schools and directions of International Relations research are actively developing, such as neoclassical realism (G. Rose, J. Mearsheimer, W. Wohlforth, F. Zakaria), constructivism (R. Jackson, J. Ruggie, G. Sørensen, A. Wendt), postcolonialism (H. Bhabha, E. Said, G. Spivak), feminism (C. Hooper, C. Reus-Smit) etc. Thus, global international relations aspires to level the playing field and to develop a genuinely inclusive and universal discipline that truly reflects the growing diversity of its International Relations scholars and their intellectual concerns. 


\section{Conclusion}

In summary, the conceptual analysis of the evolution of International Relations and the sciences of International Relations during the XX-XXI centuries on the basis of fundamental research by Western scientists allows us to state their essential changes under the influence of two world wars, revolutions, globalization, decolonization and changes in the ratio of forces between the centre and the periphery. The result was the gradual modernization of the Westphalian world order and its transition to the Post-Westphalian world and post-bipolar international relations after 1989. At the same time, over the last century, the discipline of International Relations has been established and developed. Its organizational and institutional development is mainly related to the Western tradition and with less involvement of non-western scientists. As analysis of the work of Amitav Acharya and Barry Buzan shows, further scientific understanding of these processes is a particular challenge for representatives of various scientific schools and trends in the study of the origins, nature, and features of modern international relations.

\section{References}

Acharya, A., B. Buzan (2019), The Making of Global International Relations. Origins and Evolution of IR at its Centenary, (Cambridge: Cambridge Univeristy Press).

Ashworth, L.M. (2014), A History of International Thought: From the Origins of the Modern State to Academic International Relations, (London: Routledge).

Barry, B., O. Wæver (2003), Regions and Powers: The Structure of International Security, (Cambridge: Cambridge University Press).

Buzan, B. (2004), The United States and the Great Powers, (Cambridge: Polity).

Huntington, S. P. (1999), The Lonely Superpower, "Foreign Affairs", 78(2): 35-49.

Kapstein, E. B., M. Mastanduno (1999), Unipolar Politics, (New York: Columbia University Press).

Rosenberg, J., (2016), International Relations in the Prison of Political Science, "International Relations", 30(2): 127-153.

Wohlforth, W. C., (2009), Unipolarity, Status Competition, and Great Power War, “World Politics", 61(1): 28-57.

Zakaria, F. (2009), The Post-American World and the Rise of the Rest, (London: Penguin Books). 
